\title{
From the Secular to the Sacred: The Influence of Sufism on the Work of Leila Aboulela
}

Billy Gray

Dalarna University

Critique is most powerful when it leaves open the possibility that we might be remade in the process of engaging another worldview, that we might come to learn things that we did not already know before we undertook the engagement.

Saba Mahmood (2005)

Islam as a religion is the unwelcome guest at the feast of Western secularism.

Geoffrey Nash (2012, p. I 5 )

Prominently viewed as, alternatively, an Arab, African, Muslim or diasporic woman writer, Leila Aboulela has contributed significantly to the emergence of a form of literature which, according to Dalla Sarnov, is "neither Arabic nor English but is linguistically and culturally hybrid, discursively multidimensional and literarily heterogeneous"(20I4, p. 70). Since the publication of her first novel, The Translator, in 1999, her fiction has attempted to decode the culturally unfamiliar and represents the embodiment of what has been termed "insider" narratives originating from Arab or Islamic sources. Arguing that Aboulela's texts represent "an acculturation to globalisation conducted from within the territory of the dominant discourse," Geoffrey Nash defines her work as a prominent example of contemporary transnational literature, as it "embodies the issue of the transportation of

How to cite this book chapter:

Gray, B. 202I. From the Secular to the Sacred: The Influence of Sufism on the Work of Leila Aboulela. In: Jonsson, H., Berg, L., Edfeldt, C. and Jansson, B. G. (eds.) Narratives Crossing Borders: The Dynamics of Cultural Interaction. Pp. I45-I68. Stockholm: Stockholm University Press. DOI: https://doi .org/IO.I6993/bbj.g. License: CC-BY 4.0 
specific Arab/Islamic ideologies into a literature composed for a non-Arab/Islamic audience" (2007, p. 4). The "transportation" Nash refers to here can be viewed as a conscious attempt to facilitate the type of cross-cultural awareness that is such a significant element within contemporary Anglo-Arab Women's writing. However, while such writers undoubtedly share a certain commonality in relation to their use of transnational literary frameworks, it is evident that within Anglo-Arab women's writing there exists a variety of positions in relation to the questions pertaining to nationalism identity, feminism, etc., and Nash has argued that, in terms of Arab migrant literature, Leila Aboulela's fiction can be said to "represent, more or less, a school of one" (2012, p. 44). This singularity resides in the fact that, in her fiction, the religious framework functions not merely as a term of reference or a representative aspect of cultural and social norms, but is deliberately presented as a faith; moreover, it is a faith which is ultimately positioned as a viable alternative to secularism and specific elements of Western modernity. While adopting an archetypal Western fictional form, Aboulela's texts embody a specific Islamic moral and religious terrain and promote the legitimacy of what can be termed "a faith-based subject position." (Dimitriu, 20I4, p. I20). This religiosity includes numerous elements which go beyond the political, cultural and ethnic markers of identity commonly found in Anglo-Arab fiction and functions as "an antidote to hegemonic materialism and existential emptiness.” (Nash, 2007, p. I36). Essentially uninterested in portraying Muslim identity as a cultural or political artefact, she depicts the psychology and moral imperatives of individuals who embrace religious certitude. This desire to incorporate characters who are practising Muslims into contemporary English language literary fiction and produce novels that are infused with traditional Islamic aesthetics, necessarily entails the charting of a new literary space as there currently exist remarkably few examples of such characters in contemporary literature. As Mahmudul Hasan has noted, those fictional representations that do exist invariably conform to the ubiquitous crass stereotyping increasingly evident in media discourses, such as "the Islamic terrorist," "the oppressed Muslim woman," or alternatively, liberal secular Muslims whose lifestyles are not noticeably different from those of non-Muslims (201 5, p. 93). What is undeniable is that Aboulela's desire to write sympathetically 
about individuals who embrace faith in a modern secular world and her desire to create fictional worlds which, in her own words, "follow Islamic logic" (Santesso, 20I3, p. 7), serve to distance her work from numerous contemporary critical discourses. Christina Phillips contends that religious belief - regardless of the specific religious denomination of affiliation which is being articulated has been essentially eradicated from the contemporary literary canon and argues that while it is permissible for literary texts to contain religious themes, characters and imagery, it is invariably the case that "if they want to be taken seriously by critics, these must be secularised" (2012, p. I66). The fact that Aboulela's characters embrace a specifically Islamic religious identification can also be viewed as an additional handicap as after the events of 9/I I, both critical and popular discourses have predominantly focused upon Islamic fundamentalism and radicalism, resulting in an increasing marginalisation of moderate Muslim religious subjectivities. Ashi Nandy is one observer who has noted the tendency of secular states to perceive the followers of the Islamic faith as "demonic others that need to be deforged" (Nash, 20I 2, p. I 5). In relation to literature, Tariq Ali has employed the term "the belligerati" to describe writers such as Martin Amis, Salman Rushdie and John Updike, who associate religious belief - and in particular, Muslim religious belief - as indicative of a form of cognitive paralysis, a delusional psychology deeply embedded in, and inextricably connected to, political radicalism and intolerance. In addition, "faith-based fiction" has invariably constituted a domain that resides outside the established nostrums of postcolonial theory, which has been distinguished by an unmediated, aggressive form of secularism. Nash has bemoaned what he describes as "the dearth of useful post-colonial theoretical material germane to the issue of religion or the sacred as a key conceptual category" (20I 2, p. 5), and writer Sara Mahood has evinced frustration with Post-colonialism's stubborn denial of what she terms "valuable forms of human flourishing outside the bounds of a liberal, progressive imaginary" (Dimitriu, 20I4, p. I24), which includes a disdain for non-Eastern, non-secular modes of agency.

Aboulela has herself directly alluded to some of the recurring difficulties she faces when attempting to write sympathetically about individuals who embrace religious faith in an antagonistic secular world: 
I want to write about faith but it is so difficult to talk about this when everyone else is talking about the political aspects. I'm concerned that Islam has not just been politicised but that it is becoming an identity. This is like turning religion into a football match, it is a distraction from the real thing. (Edwin, 20I3, p. 58).

This raises the important question of what Aboulela actually means when, in the above quotation, she refers to "the real thing." Equally, in what respects can her fiction be said to embrace Muslim aesthetics and how are these aesthetics given literal representation in her texts? In general terms, the religious imperative she describes is essentially a voluntarist one, as she articulates the lifestories of Muslim women who are neither victims nor escapees of Islam but willingly committed to their faith. ${ }^{\mathrm{I}}$ She also challenges one of the major misconceptions about Islam currently held in the West, which perceives the Sharia as a legal prerequisite enforced by a government to the moral conduct of the individual, a desire to follow the spirit of the Prophet Muhammad's teachings as well as a recognition of the validity of this teachings legal precepts. Equally noteworthy is how these same protagonists view the concept of Jihad as a theological legitimation of their internal struggle against spiritual atrophy and imperfection rather than an obligation to eradicate apostasy or engage in gratuitous acts of violence against non-believers. It is my contention that a detailed reading of Aboulela's fiction reveals how these perspectives, and indeed other, less overt elements contained within her texts are profoundly influenced by what can loosely be termed "Sufi dialectics," as many of her protagonists embark upon spiritual journeys characterised by experiences strikingly similar to those embedded in traditional Sufi practices. The aim of this essay, therefore, is to delineate how Sufism's perspective on the relationship between esotericism and exotericism, its views on the necessity of a spiritual guide, its belief in the value of spiritual submission, together with its emphasis on the importance of prayer, have all exercised an

I In the current political climate, this is an unusual position to take. For example, in an essay on immigrant Muslim writers in Germany, George Stock points out that a desire to distance oneself "from Islam is a constantly recurring theme for female characters who are often treated by women immigrant writers." See Nash, 201 2, p. 64. 
unmistakable influence on Aboulela's desire to create characters who attempt to live Islam fully in all of its various dimensions. ${ }^{2}$

\section{Sufism: Outer and Inner Manifestations}

What then is Sufism? Max Weber once described it as "an orgiastic collectivistic fanaticism," and several decades later, F.A. Tholuck wrote that, in comparison to Christian mysticism, Sufism was "a primitive spirituality" (both quoted in Greaves et al., 2009, p. I). Although the question of Sufism's relationship to Islam is one of the most contested issues within contemporary Islamic discourse, and the belief that Sufism and Islam are distinct and separate entities is common in the West, in reality, as Eric Geoffrey has indicated, there is ample evidence to suggest that Sufism lies at the heart of Islamic culture and is far from being a marginal or deviant phenomenon in relation to Muslim belief (20I0, p. xvii). It is said by its adherents to be peculiarly resistant to any form of systematic or external study as its very diversity prevents it from being schematised in a static or permanent manner. What can be said with certainty as that the Sufis often depict their activities as the operation of a form of cognition which is linked with human spiritual

${ }^{2}$ It is important at this juncture to note how all the textual evidence suggests that Aboulela has been influenced by what can be termed "traditional Sufism," rather than the variant commonly taught in the West and frequently referred to by scholars, somewhat contemptuously as "NeoSufism." "Neo-Sufism was essentially popularised by figures such as the Greek-Armenian George Gurdjieff (I866-I949), the Russian mathematician and philosopher Pytor Ouspensky (I878-I947), Alfred Richard Orage (I878-I934), editor of the influential New Age magazine, J.G. Bennett (I897-I974), a British scientist and suspected spy and, most recently, Idris Shah (I924-I996), believed to have been the foremost exponent of Neo-Sufi ideas in the West. Limited space prohibits a detailed explication of the various ways in which Neo-Sufism differs in its essentials from Sufism in its classical form; in general terms, it can be described as propagating a psychological system rather than a faith-based theological exegesis and is essentially non-denominational in nature, unlike traditional Islam, which is inextricably linked to Islam. James Moore has claimed that the type of Sufism popularised by Idris Shah is "without self-sacrifice, without self-transcendence, without the aspiration of gnosis, without tradition, without the Prophet, without Islam and without God. Merely that.” See Moore, I986, p. 7. 
development and that a major component of Sufis is that there exists an Absolute of which ordinary, perceptible things are to be regarded as local concretizations. They contend that Man is essentially a reflection or emanation of this Absolute Being and that all multitudinous forms of phenomena which exist in the temporal world are merely manifestations of this Being's various attributes. The material and the metaphysical are therefore linked in a form best regarded as a continuum and the eternal and phenomenological planes of reality are tow complementary aspects of what the Sufis term the "One." A Sufi dictum is "Man is the microcosm, creation the macrocosm - the unity. All come from one" (Arasteh, I980, p. I9). Humanity is part of an eternal whole from which everything is derived. However, although Man began life in an unconscious union with such forces, he separated from nature in his process of evolution, thereby experiencing pain, time and space. Despite appreciating what his purpose was before assuming human form, Man forgot what this consisted of at the time of birth. The Sufis believe, however, that the individual can ultimately reunite with his origins. Authentic Sufism, therefore, is played out in a harmony which the initiate must continually restore between the body and the spirit, and between institutionalised religion as it was established on earth and its inner reality. This is why one of the goals of Sufism is to pierce the opacity of this world in order to contemplate the spiritual realities that lie beyond simple faith and the Sufi undertakes "labours", in order to reach a condition of spiritual realisation. Thus, Sufism is essentially an initiatory path which enables the transmission of spiritual blessings, referred to as "Baraka." The aspirant progresses along the path in order to go beyond the limits of individuality - potentially or in actuality - and to reach spiritual understanding.

In an early Sufi manual entitled Kitabitt-Luma (The Book of Flashes) by Abu Nasr Al-Sarra (d. 988), Sufis is defined as "the science of openings," as God wills the process of "opening up" the human heart to divine inspiration (Elmarsafy, 20I 2, p. 2). This is achieved by an "unveiling" of the spiritual realities that define our existence, and for the Sufis, this "unveiling" represents the principal mode of access to the supra-sensible world. Following long inward effort, the initiate will have access to spiritual realities thanks to the progressive lifting of the veils which mask the 
realities of his condition. Sufi practice initiates the raising of the veils which the world of the senses throws over Man, thus allowing him to reach the world of the spirit. This "unveiling" leads to the direct perception of spiritual certainties and is an essential part of Sufi epistemology.

This emphasis upon "unveiling" implies that Sufis look beyond mere form and it is true that Sufis distinguish between the "World of Testimony," i.e. the perceptible world, and the "World of Mystery" (the Ghayb), the latter being defined by "that which is not accessible to sight" (Geoffrey, 20I0, p. 2). Traditional Sufi literature emphasises the transformative power of the inner dimensions of the Revelations given to Muhammad and contains numerous warnings that many ritual acts have no essential meaning or effect if performed without the requisite intention. In this respect, dogma and conventional liturgy operate as bases not ultimates and religious truth does not reside in the replication of mere form. Sufis point out that, in the Koran, God represents Himself as, concurrently, the Outer (al-zahir) and the Inner (al-Batin), and while not denying the literal meaning of the Holy Book, they impress upon the appellant the importance of discovering other, hidden meanings which a Koranic verse may, consciously or otherwise, conceal (Geoffrey, 20I0, p. I). Each act of worship includes an aspect which is apparent and another which is hidden, representing in the words of the great Sufi philosopher Al-Ghazi "the peel and the pulp" and while the particular form of an external act is never glossed over, it is viewed as a support, rather than an essential component of, spiritual realisation. To the Sufi, "Reality is hidden within the law as butter is hidden within milk," and they contend that human consciousness must penetrate beyond the outer forms if the real meaning of religion is to be understood. The famous Persian poet Rumi has explained this belief in the following words:

Split the shell, so that you may arrive at

Meaning's pith; cleave through the flotsam

and jetsam that floats, along with the foam, on the surface of the sea to arrive at the purity of the sea's depth. (Lewis, 2000, foreword). 
This advice is reiterated in the words of the Sufi teacher Khawaya Pilad of Erivan, who advises the disciple to "Penetrate beneath the outward message of the symbol or you will put yourself to sleep. Within the symbol there is a design which moves. Get to know this design" (Shah, I982a, p. 43).

It is important to emphasize, however, that this essential component of Sufi dialectics has given rise to several popular misconceptions regarding both the aims, and the origins, of Islamic mysticism. For some, Sufism is perceived as something akin to a new age philosophy and its suprarational - as opposed to irrational - character is commonly believed to have been conceived as a reaction to the narrow legalism of Orthodox Islam. In reality, traditional Sufism does not deny the outward meaning of the Koran or the world of conventional religious observance; rather, in the same way that Islam preaches the importance of balancing the realms of matter and spirit, Sufism recognises Islam in both its exoteric and esoteric dimensions. Eric Geoffroy writes "Having the Koran as its source, Sufism is based on the example of the Prophet. Therefore, it in no way rejects either the law or the rights of Islam. On the contrary, it ultimately illuminates them from within" (20I0, p. xvii). Sufism, a specific path intended to develop the higher states of consciousness, begins with daily life and the world of forms and rites. The external forms of worship - such as the Five Pillars of Islam - are, above all, ways to move towards spiritual realities and primary function as "symbols put into action." To the Sufis, formal and institutionalised religion fulfils an essential function and they believe that religious symbolism operates as a reflection of what they perceive as objective truth. Each act of worship includes a component which is visible and one that is hidden, and the Sufis, when illustrating the fundamental compatibility of the external and internal elements of their teachings, often refer to the Prophet Mohammad's comment that "The law is my word, the Path my acts and reality my inner state" (Geoffrey, 20Io, p. 60). Within the realm of Sufi action, therefore, exist both inner and outer activities, each of which is given equal significance and the external form of religious observance is believed to function as a support for spiritual awakening. The inextricable connection which exists between the esoteric and the exoteric aspects of Sufism is confirmed by Rumi in the following words: "the 
law of religion is like a candle that shows the way; without that candle we cannot even set foot on the spiritual path. Once the way is lit with the light of the law, the wayfarer begins his spiritual quest which takes place on the Sufi path" (Lewis, 2000, p. 87). The Iraqi Sufi scholar Alusi ( 1853 ) echoed these sentiments when he wrote: "He who claims to know the secrets of the Koran before having mastered the exoteric commentaries of the Book can be compared to he who claims to have reached the innermost part of a house without having passed through its door" (Geoffrey, 20Iо, p. 4I).

\section{Sufism in Aboulela's Fiction}

Interestingly, in a recent interview, Leila Aboulela spoke openly about her belief in a faith based upon both mystical and legal precepts. When asked whether she views Islamic mysticism as a separate entity from a more Orthodox interpretation of the Koran, she replied:

No, I see them both together as being one. . Laws without any feelings are lifeless. You're just doing them because you have to do them. The result might look good on the outside, but inside the heart is dead. [Then there are] people who do everything out of love for God, yet who have rejected the Shariah... as Muslims we have to put the two sides together. (Rashid, 20I2, p. 620).

A detailed reading of Aboulela's fiction reveals the extent to which the "outer" and "inner" aspects of Sufi religious practice are visible in her texts. On an overt level, there are numerous explicit references to Sufism in her narratives and the latter reveal both a strong knowledge of, an interest in, several prominent Sufi Orders and esteemed historical figures who have been active within the Sufi tradition. The Kindness of Enemies (2015) contains an epigraph accredited to an "anonymous Sufi Saint of the twentieth century," and the novel itself contains a fictionalised account of the life of Iman Shamil (I797-I87I), an important Muslim political and religious leader from the Caucasus, who was a prominent Sheikh in the Sufi Naqshbandi Order. Another influential Sheikh from the same Order, Malanna Abdullah Ed-Dagestani, originally from Turkey, is mentioned in the same novel, and in Lyrics Alley (20II) the central protagonist, called Badr is said at one point 
to be reading Iman Ghazali's classic Sufi text The Revival of the Sciences of Religion (p. I24). The Translator (I999) contains an extract from the controversial writer Abs Nawar (75I-8I4), a historical figure commonly believed to have lived the final years of his life as a Sufi and whose poetry is deeply impregnated with Sufi mysticism. In the short story "Days Rotate" from her Coloured Lights (2OII) collection, the two main protagonists are said to listen to a diwan of Sheikh Al'Alawi, who was a Sufi Sheikh active within the classic Darqawi Shadhili tradition. Moreover, a number of Aboulela's characters reveal a detailed knowledge of Sufism, and at certain points come into contact with the more visible aspects of its teachings. In The Kindness of Enemies, Natasha attends a Sikr which is said to be performed by the same Sufi Tariquat that Iman Shamid belonged to; in Sufi devotions, Zikr - meaning "remembrance of Allah" - embodies both a solemn ritual and a spiritual state of mind. In Minaret (2006), Najwa participates in a Tafsee class, which implies that she is being exposed to a form of Sufi exegesis usually relating to the inner meaning of a specific passage in the Koran. In the same novel, Najwa asks Tamer's mother whether she has listened "to the programme on the radio about Sufism?” (p. 270). In The Translator, Rae's uncle, who has gone to Egypt in a military capacity, is said to have "become interested in Sufism [and] converted to Islam" (p. I 7), and in The Kindness of Enemies, Malak's teenage son, Oz, addresses her as "a Sufi," to which she responds "Am I a Sufi? Do you see me as such? Then you are doing me a great honour" (p. 9).

These numerous references to Sufism, classical Sufi texts and important historical figures within the movement itself, can be said to represent the "outer" or more visible manifestation of Aboulela's knowledge of Sufism; a closer and more attentive reading, however, reveals the extent to which she has accepted the validity of its "inner" dimension. Indeed, her characters' desire to embrace what can be termed "the living heart" of Islam leads them to undergo a spiritual transformation that bears a strikingly similarity to the experiences undergone by the so-called Sufi traveller on the road to self-realisation. This is partly manifested in the manner by which several of her central protagonists become involved in what can only be described as a "spiritual journey." As Mark Sedgwick has noted, many Sufis themselves, when asked 
to define what actually constitutes a Sufi, will invariably use a phrase such as "a traveller on the path back to his Maker" (2003, p. 5), and Al-Ghazali has referred to "the adept [who] travels on his way towards God" (my italics, Sedgwick, 2003, p. 29). As the most important goal of Sufism is to return Man to his original state of purity, where he was not yet separated from the spiritual world, this implies that the seeker is obligated to follow what can usefully be described as "an inward path." As Ansari Harawi (d. I089) has written in his classic text The Stages of Travellers towards God, as the Sufi progresses on his journey, he is believed to ascend a double ladder of "initiatory stations," and "spiritual states." The former are defined as the fruits of spiritual discipline, while the latter are divine favours which are granted freely to the mystic. Tariq Ramadan defines the Sufi "journey" in the following terms:

God in his Oneness put into the heart of each human being an original breath, a natural longing for the Transcendent, for him. Muslin spirituality is the work ... the believer does on the self in order to be liberated from all forms of the worship of things other than the Transcendent and to find a way [back] to this original breath and purity. (Greaves et al., 2009, p. I07).

Perhaps the most widely known Sufi text where the motif of "a journey" or a "quest" is employed as an analogy of the successive stages of human soul in search of perfection is Farid ud-Din Attar's famous The Parliament of the Birds ( I 169), in which, by employing illustrative biography, fables and maxims, the specific stages in human spiritual development are described. Two other important figures in Sufi history have employed similar terminology; Ibn Arabi frequently mentioned the concept of the Warid - literally translated as "the arriver" - in his literature and Rumi argued how, as Sufism can be defined as a process of mystical awakening, the wayfarer must begin his spiritual quest by embarking upon what he terms "the Sufi path," with the hope that "at the end of the journey, one arrives at truth" (Lewis, 2000, p. 7).

Aboulela uses a similar nomenclature in Lyrics Alley when describing Badr's search for both greater self-understanding and a closer relationship with true spirituality. Faced with economic penury and the burdens of taking care of an elderly and increasingly 
senile father, his encroaching despair leads him to question whether his suffering serves a deeper purpose:

Badr's tumultuous, humdrum life. What was it all for, where was it heading? The answer peered at him now as it had done before and would do again. His life was a journey. A journey towards the day when Allah Almighty would look at him, look through him, inside him, know him and then would call him by his name. Ya Badr. (p. 23).

Subsequently, when he visits the Umdurman district and ponders the myriad, unforeseen directions that his life has taken, he confesses how "it felt like a journey with its own hardships and elation; its anxieties and weaknesses, its greed for God's mercy, its yearning for blessings, its departure point and graceful arrival" (p. I33). The "graceful arrival" referred to here implies a potential restoration of Man's original state, when he was not yet separated from the spiritual world. In Minaret, Najwa confesses how she "yearned to go back [my italics] to being safe with God," and in Aboulela's fiction the concept of "Home" is not exclusively related to the experience of diaspora in a literal physical sense or the tribulations attendant upon voluntary or enforced exile; rather, her use of the term transcends the idea of a physical space and implies a spiritual "homecoming" where, after overcoming numerous obstacles, the seeker achieves a spiritual reunion with God. To arrive "Home" involved embracing the inner dimensions of the Revelation given to Mohammad and developing the ability to, as Natasha in The Kindness of Enemies expresses it, "delve into the hidden truth behind the disguise" (p. I07). In The Translator, for instance, the narrative implies that if Rae, a Scottish academic fascinated by Middle Eastern politics, is to truly understand Islam, he must relinquish a fascination with its cultural manifestations and actively embrace the inner dimensions of the faith. As Sammar comments "He would not understand it [Islam] until he lived it" and she is insistent that he "look beyond the causes to the First, the Real” (p. I02).

\section{The Teacher-Disciple Relationship}

The difficulty which several of Aboulela's characters face is that they cannot access "the Real," without guidance from spiritual 
teachers who have supposedly transcended ordinary limitations and embraced the imperatives of esoteric knowledge. This is why her texts are replete with protagonists who act as spiritual mentors - and in certain instances, self-proclaimed Sufi teachers - for the aspiring individual who desires to penetrate beyond the nominal significance of meaning. The recurrent motif of the teacher-pupil dynamic in Aboulela's fiction can be directly traced to the influence of Sufism on her work as, in their proper application, Sufi teaching techniques depend upon an interrelation between the Master and his disciples. In relation to both the history and praxis of Sufism, a system of discipleship to spiritual teachers originated which involved the aspirant developing his spiritual proclivities under the supervision of a guide. This guide operates as a link between the disciple and his objective and is ultimately responsible for organising and shaping the inherent flexibility of the Sufi work. By practising a variety of structured activities, the teacher endeavours to transmit to the pupil the "Baraka" - an impalpable force imparted to people, situations, places and objects for a specific reason - he receives from his own master. This Baraka impacts upon the pupil according to the time, place, need and the circumstances in which he finds himself. As Idries Shah notes: "To be a Sufi and to study the Way is to have a certain attitude. This attitude is produced by the effect of Sufi teachers, who exercise an instrumental function in relation to the seeker" (Shah, I982 b, p. 24).

The conviction that spiritual guides are essential and exercise an instrumental function in relation to the seeker is prevalent in many of Aboulela's texts, not least in two specific stories contained within her Coloured Lights collection. These stories - entitled "Radia's Carpet" and "Days Rotate" respectively - are particularly significant in relation to the "teacher-disciple" dynamic and both resonate with a detailed Sufi symbiology. In "Radia's Carpet," Dia, the thirteen-year-old boy of the narrative, is engaged in a formal competition to win a carpet which supposedly contains magical qualities. The suggestion is that Dia must first achieve a degree of spiritual awareness if he is to be deemed a worthy inheritor of one of the seven carpets which are passed on only when their owners die. In order to acquire the necessary self-awareness, Dia is instructed by a spiritual teacher, who informs him that he will only win the esteemed prize if he rejects the base emotions of 
greed, envy and self-interest. We are told how "the Teacher talked and Dia absorbed," and the latter is advised to "Reign in your ego, ride it, don't let it ride you" (p. I 47). It is only by acknowledging how his "ego is as big as the moon and just as familiar," that Dia, through instruction from an appointed spiritual guide, can be said to have achieved the degree of spiritual maturity necessary to be able to take his place within the community of believers.

Similarly, in "Days Rotate," a futuristic, post-apocalyptic narrative which shares some superficial similarities to the concluding sections of Doris Lessing's novel The Marriages of Zones Three, Four and Five, - a text which, interestingly, is also permeated with Sufi dialectics, - Aboulela's protagonist is a young girl who is engaged in a perpetual, seeming never-ending, physical ascent of an unnamed geographical terrain. Set in a time period when “all struggles [have] become spiritual struggles," the adolescent narrator is accompanied by a guide, an older male accomplice, who frequently instructs her to "empty yourself." Bemoaning that this is impossible as she is "covered in a thick rubbery skin, like an elephant" (20IIa, p. 32), she beseeches her guide and teacher to "carry me." The physical ascent is symbolic of the protagonist's spiritual evolution and her journey is concluded when she, like her teacher, transcends human limitations and can literally "fly." This spiritual breakthrough, made possible by the guidance of her teacher is described as resembling a condition of nirvana-like consciousness: "why did I think I could never make it [that] I could never reach this place? Here was what I had always wanted, every colour and every sound" (201 Ia, p. I39).

Aboulela's interest in the teacher-disciple dynamic is taken a step further in The Kindness of enemies, through the parallel narratives of Shamil and Natasha, whose interrelated stories are separated by a timespan of over two hundred years. The former's spiritual teacher is called Sheik Jamal-el Dinal Husayni, "the gentle Sufi scholar," and we are informed that Shamil "had soaked up the Sheikh's Sufi teachings, eager for enlightenment, eager for the grace and strength that came from the Creator" (2015, p. I6I). Together with his friend Ghazi Muhammad al-Ghimrawi, "they had known that perfection could not be reached without the instructions of a Master; they were seekers and Sheik Jamal el-Din 
their spiritual guide" (20I 5, p. I6I). Natasha, a modern, intellectual and avowedly atheistic young woman, has embarked upon a research project relating to Shamil's role as a rebel leader engaged in resisting Russian imperial expansionism, and her exposure to his Sufi beliefs begins to have an increasingly resonance in her own life. She is introduced to a mysterious actress called Malak through her relationship with the latter's son, nicknamed "Oz," who has an abiding interest in Islam and the political ramifications of Jihad. This somewhat complicated tripartite configuration is partly used by Aboulela as a means of exposing current debates relating to secularisation, assimilation and Islamophobia; more importantly, however, it soon becomes clear that Malak is assuming the role of a spiritual guide, both to $\mathrm{Oz}$, and in particular, Natasha. Moreover, it soon becomes clear that Malak's guidance is explicitly predicated on specific Sufi principles. For example, in an early passage of the novel Natasha writes in a notebook how Malak has informed her that "Sufism is based on the belief that the seeker needs a guide. Even Muhammad, on his miraculous night's ascent through the seven heavens needed Gabriel as his guide" (20I 5, p. I07). Natasha's initial reluctance to embrace the role of a spiritual novice is partly based on her fear of abrogating individual agency and also related to a sense of confusion regarding exactly how a teacher-disciple relationship is initiated. She asks herself "If I ever started to seek the kind of knowledge that couldn't be found in books, who would I want as a guide? Does the student seek the teacher or the other way around?" (2015, p. 107). She subsequently comes to a realisation that Malak has already been performing the role of teacher without her, Natasha, being fully aware of exactly how this spiritual knowledge has been transmitted. Eventually she perceives that Malak "had orientated me towards the unexpected and guided me to what could never be written down in history" (2015, p. 69). She continues by adding "I had come to her today, needing to connect ... perhaps it was time to acknowledge that what I was after was spiritual. She was ready to be a guide and I would fight my weaknesses in order to follow" (2OI 5, p. 3 I 4 ).

For characters such as Natasha and Shamil, the willing acceptance of the role of supplicant within the confines of a 
traditional teacher-disciple relationship, involves a reassessment of commonly held beliefs relating to the value of autonomy and free will. Aboulela's fiction suggests that submission, both to the dictates of a spiritual guide and an omnipotent Higher Power is a fundamental prerequisite if the aspirant is to experience spiritual enlightenment. Likewise, Sufism emphasises that to truly become a disciple the individual must embrace a condition in which one has voluntarily given away one's freedom in certain areas to those better fitted to guide one than one is oneself. This involves the aspirant practising what is termed "trusting self-abandonment in God". To the Sufi, secular ideas relating to "freedom" are only a convenient chimera, as they contend that the average individual is controlled by his/her lower instincts - referred to as the nafs" or "secondary self" - which negate the possibility of genuine free choice. The function of this "secondary self" is to interpose a wedge between objective reality and the real essence of the individual and the teacher-disciple relationship is best understood as a practical programme designed as a means of controlling the "nafs." The most obvious sign that the "secondary commanding self" has been brought under control is that the disciple "achieves ontological servitude while at the same time putting himself at the service of Men" (Sedgwick, 2003, p. 27). As Ahmad Mustafa Sarmouni suggests, this condition implies freedom from choice: "freedom is one of the factors that most confuse and undermine you. It gives you full play for your neuroses, your surface reactions and your aberrations" (Lefort, I97 I, p. I IO).

This ontological servitude is a position to which several of Aboulela's characters aspire. Shamil, for example, asks himself whether he has the spiritual strength to oppose "those who claim they're acting in the name of Islam and at the same time don't follow the principle of submission" (2015, p. 176). His son Jamaledin, who is also involved in a spiritual quest reflects upon how "Sins were like dirt, they could be washed off. More serious was the core submission, the foundation of belief." In The Translator, Sammar, on a temporary visit to her Sudanese homeland, comments approvingly on "the feelings all around of surrender" and while resident in Scotland she explains her views in more detail: "My fate is etched out by Allah Almighty, if and 
who I will marry, what I eat, the work I find, my health, the day I will die are as He alone wants them to be. To think otherwise was to slip down, to feel the world narrowing, dreary and tight" (I999, p. I7I). Perhaps not surprisingly, Aboulela's emphasis on submission as being an essential component of religious life has proven to be somewhat problematical for certain critics, who view Sammar's and, in particular, Najwa's seeming retreat from hardwon Western freedoms as evidence of a regressive mindset. In Minaret, Najwa's burgeoning spiritual awakening, accompanied as it is by a parallel interest in the accruements of conventional religious attire, has been viewed with scepticism by some commentators, who have expressed impatience with what they interpret as "the topography of withdrawal" seemingly evident in Aboulela's fiction. One academic has gone so far as to accuse Aboulela's texts of reinforcing "the clichés of Islam as oppressive, anti-feminist and anti-individualistic" (Santesso, 20I3, p. I03). Eva Hunter has expressed disquiet concerning what she terms "Minaret's quietist solution" for Najwa and Sadia Abbas contends that "Aboulela's novels when most committed to religion and Islam, reveal themselves as most in line with the idea that religion is a brand of socio-psychic tranquilizer" (Abbas, 20I I, p. 453). Such criticisms, while doubtless valid on their own terms, are predicated on a secularist, supposedly "progressive" ethos where the perception of "submission" in any shape or form is viewed as synonymous with subjugation and even oppression. If approached from the perspective of Sufi philosophy, however, Aboulela's belief that within the sphere of spirituality, submission and individual agency are by no means incompatible, acquires greater legitimacy and contextualisation. Whereas a critic such as Esra Santesso states unequivocally that "At the end of Minaret, Najwa is unquestionably less free than she was at the beginning" (2013, p. I04), Aboulela's views on the so-called sanctity of freedom when divorced from submission to God's will are aptly summarised in the following quotation by the Sufi Pir David: "Do you know, can you comprehend what freedom it gives you to have no choice? Do you know what it means to be able to choose so swiftly and surely that to all intents and purposes you have no feed choice?” (Lefort, I97 I, p. I Io) 


\section{Intentional Suffering}

For the Sufis, submission, both to a teacher and to the will of God, is inextricably linked to the experience of conscious or intentional suffering, and they view the latter as symbolising not only the essence of the human condition, but also a kind of "litmus test" of the disciple's commitment to the religious path. This belief is aptly summarised by the Sufi dictum "Sometimes He gives while depriving you" (Sedgwick, 2003, p. I I2). In the same way that physical austerity, correctly used, operates as an antidote to irrational desire, an element of stress or suffering in one's immediate circumstances acts as a catalyst for spiritual renewal and regeneration. The experience of suffering can be inherently beneficial, as absolute contentment deflects the individual away from the desire to attain spiritual advancement. It exists, not as something to be avoided, or as wanton punishment, but as an opportunity for the disciple to confirm his strength of faith. This is why, as Eric Geoffrey explains, "true Sufis, who are in search of excellence or Ihsan, often take upon themselves greater burdens than do other Muslims" (2010, p. 6I).

This tenet of Sufi philosophy has had a significant influence on Aboulela's fiction and is exemplified in the manner by which many of her characters are, when faced with diminished material and emotional circumstances, obliged to reassess their situation and the ultimate value of adhering to an overtly secular perspective on life. In The Translator, Sammar's husband dies suddenly in a car accident and this traumatic experience, allied with a prolonged period of suffering, proves conductive to a process of spiritual rebirth. In Minaret, Najwa, who is originally from an established and respected upper middle-class family with important connections to the privileged echelons of Sudanese society, is forced into exile where, in order to survive economically, she accepts employment as a maid to a prosperous Middle Eastern family. This reversal in fortunes erodes her sense of self-worth while simultaneously acting as a catalyst for her subsequent appreciation for the religious way of life; as she comments, "slowly, surely, I was setting at the bottom ... and there buried below was the truth" (2006, p. 240). It is in Lyrics Alley, however, where this theme acquires greatest significance as the characters of Badr serves as 
a fictional vehicle for Aboulela's desire to investigate the intimate relationship between suffering and faith. Intermittently employed as a teacher and private tutor, Badr and his ever-growing family of dependants live in a cramped domestic abode which becomes even more crowded when he assumes responsibility for his increasingly confused, ill and elderly father. A deeply religious man, Badr's faith is frequently tested by a series of seemingly inexplicable misfortunes, affecting both himself and others, and he begins to question the value of suffering in a world where compassion is ignored in favour of political manoeuvring and financial greed. Ultimately, he comes to the conclusion that suffering exists, not as a punishment for spiritual transgressions, but as a trial and a way "of being drawn into the company of the Lord" (201 Ib, p. I67). When his best-laid plans are thwarted or suffer a major setback, he asks himself the question "why do bad things happen?" and remembers how the Prophet Muhammad "peace be upon him, said "When Allah loves a people, He tries them" (201 ib, p. I67). He surmises that: "Perhaps the shortest journey to Allah is through the disliked, uncomfortable choices. The seeker asks "where shall I find the Divine? The answer is 'Come close to illness, poverty and oppression. Dwell for enough time (too long would be counter-productive) in those shadows where laughter does not come easily to the lips" (20I Ib, p. 2I4).

In the above quotation, Badr describes the relationship between the seeker and God as an interactive one, based on enquiry and guidance. To the Sufis, this dialogue is often characterised as governed by what they define as "illuminations" and "revelations." The Egyptian poet Abu Al-Sabur (I93 I-8I), in his commentary on the key Sufi text entitled The Risala, discusses the existence of what he terms "openings" and suggests that they can be viewed as "glimmers," "dawnings" and "flashes" which can live on in the course of an individual's identity (Elmarsafy, 20 г 2, p. 2). J.G. Bennett relates these experiences to the Sufi concept of Djarkhom, the correct application of which results in the disciple being subjected to what he calls "a powerful and unexpected illumination" ( 1984, p. 78). It manifests itself in a form of "spontaneous waking" which, according to Bennett, functions as "the foundation of all our possibilities of transformation" ( 1984, p. 78). Tariq 
Ramadan goes further and links these experiences to the concept of dhaki (literally translated as "Remembering"), whereby specific Islamic practices, in particular that of repetitive prayer, can be perceived as a means of reconnecting with the unity which once existed between God and Man” (Sedgwick, 2003, p. 38).

\section{Prayer as Ritual}

A belief in the act of prayer as a conduit to a different dimension where temporal barriers between the individual and God are dissolved, is fundamental to Aboulela's perception of the spiritual possibilities that lie within the domain of religious observance and ritual. On one level prayer acts, not only as a solace in a world partly defined by suffering and emotional pain, but also as an antidote to personal fragmentation, a reminder as it were, of an alternative space where existential anguish is replaced by spiritual possibilities. In The Kindness of Enemies, we are told how "prayer lulled Jamaledin to spaces where the pain subsided" and in The Translator, Sammar reveals how the sense of certitude she experiences when engaged in ritual prayer leads to "the splinters inside her coming together" (I999, p. 6I). In Minaret, mere observance of worshippers engaging in the act of prayer, without actively participating in the ritual itself, draws Najwar's attention to what she terms "that hollow space," where she feels a bleakness defined by emotional numbness. Frequently prompted by Waafa - her friend and mentor - to reengage with the ritual act of prayer as an external symbolic representation of her increasing orthodoxy, Najwa ponders that "perhaps that was where the longing for God was supposed to come from" (2006, p. I35). When she subsequently begins to attend her local mosque on a regular basis and becomes increasingly exposed to both prayer and the importance of the Koran, she confesses to experiencing "a breakthrough in my understanding" (2006, p. I 85 ). It is significant that Najwa defines this breakthrough as "a learning, fresh as lightening" as this description is strikingly reminiscent of the "flashes" and "glimmers" described by the Sufis as symbolic manifestations or "markers" of the disciples increasing connection with the spiritual realm. Moreover, other important characters in Aboulela's fiction are said to experience similar illumination 
while engaged in the ritual of prayer and are able to enter into contact with the "cracks and transparencies through which that other world could, at times, be sensed." Sammar, in her attempt to guide Rae towards a fuller appreciation of Islamic practices, turns to prayer as a means of purging herself of the selfish motivations she harbours for wishing to facilitate his conversion. Her success is defined by the fact that "the more she prayed for him" the more she experiences "vivid, sudden moments of illumination" (I999, p. I 89). In Lyrics Alley, Badr, when joining a throng of pilgrims intent upon answering the call to prayer, is said "to experience the thinning of the barriers," whereby he is able to sense the intimate connection that exists between the living community of believers and the invisible realm of the dead. As he takes his position in the front row of the mosque:

he sensed the congregation swelling with invisible worshippers. So palpable was their presence that it was as if the barriers separating their world from that of Mankind had thinned and become transparent. Badr felt himself slide into another dimension. It was unexpected and unasked for. A dip into an alternative state where he was weightless and free and his concerns, valid and pressing only minutes ago, slackened and moved away. (20I I b, p. 58).

Badr defines this "dip into an alternative state" as a co-mingling of two separate dimensions: "All that had happened was that two worlds, the spiritual and material, had touched each other briefly before moving on, each faithful to its own orbit” (201 I b, p. 79).

\section{Conclusion}

This article has attempted to show how Leila Aboulela's fiction contains numerous thematic concerns which are essentially based on elements of Sufi dialectics and argues that the comingling of seemingly separate realms, in this case the spiritual and the materi$\mathrm{al}$, is reflected in the ways her novels combine elements of both the secular and the sacred. Specific components of Sufi thought and belief, such as the importance of the Teacher-Disciple relationship, the value of intentional suffering and the spiritual significance of prayer have been shown to hold particular significance for many of her characters. This raises the issue of Aboulela's intentions and 
whether her fiction, influenced as it is by traditional Sufism, can be viewed as embodying a kind of literary equivalent of preparatory Sufi teaching materials, whereby the Western reader is exposed to a "glimpse" or an approximation of the objective Sufi experience. It would be remiss not to mention, however, that according to the Sufis themselves "Sufism can only be studied by means of itself," and any exposition of Sufi principles - be through the genre of literature or otherwise - will inevitably fail to encapsulate the true essence of what it is they teach. Daggash Rustari has written: "Knowledge comes from experience and cannot be learned from a book. You can read the great ones, Rumi, Jami, Hafiz, Saadi, but their writings are only the salt of the bread. To taste the loaf you must eat the loaf, to experience the salt in tis intimate relationship with the flour, the yeast and the water" (Lefort, I97I, p. I04).

Aboulela's texts do, nonetheless, provide the reader with a thoughtful and nuanced perspective on a mystical path which has increasingly, at least within the context of contemporary Western popular culture, become almost totally decontextualized from its Islamic roots. In this respect, her fiction fulfils the criteria of “Transcultural literature" as outlined by Jamal Mahjoub, who argues that such literature

demands more, both of the reader and the writer. It does not have the support of those cheering, waving crowds, who would like you to be European or Third World, Black or African or Arab. It can rely on that thin crack of light which lies between the spheres of reader and writer ... gradually that crack grows wider and wider and where there was once only monochrome light, now there is a spectrum of colours. (Quoted in Nash, 2007, p. II).

Aboulela's ability to articulate the intimacy of faith, the experience of worship and the validity of traditional Islamic mysticism to a Western audience, certainly contributes to "the spectrum of colours" outlined by Mahjoub as representative of transcultural literature and, for this reason alone, her fiction can legitimately be said to represent a uniquely fascinating body of work.

\section{References}

Abbas, S. (20I I). "Leila Aboulela, Religion, and the Challenge of the Novel," Contemporary Literature, 52(3), pp. 430-46I. 
Aboulela, L. (I999). The Translator. Grove Press.

- (2006). Minaret. Bloomsbury.

- (20I I a). Coloured Lights. Polygon.

- (20I I b). Lyrics Alley. W\&N.

- (2015). The Kindness of Enemies. W\&N.

Arasteh, R. (1980) Growth to Selfhood: The Sufi Contribution. Routledge and Kegan Paul.

Bennett, J.G. (1984). Talks on Beelzebub's Tales. Turnstore Press.

Dimitriu, I. (20I4). "“Crossing and dwelling': home as a state of mind in Aboulela's Minaret and Gordimer's The Pickup" Scrutiny 2, I9(I), pp. II9-I34.

Edwin, S. (20I3). (Un)Holy Alliances: Marriage, Faith, and Politics in Leila Aboulela's The Translator. Journal of Middle East Women's Studies 9(2), pp. 58-79.

Elmarsafy, Z. (2012). Sufism in the Contemporary Arabic Novel. Edinburgh UP.

Geoffrey, E. (2010). Introduction to Sufism: The Inner Path of Islam. World Wisdom.

Ron Greaves, R., Dressler, M. and Klinkhammer, G. (eds.) (2009). Sufism in Western Society. Routledge.

Hasan, M. (2015). "Seeking Freedom in the 'Third Space' of Diaspora: Muslim Women's Identity in Aboulela's Minaret and Janmohamed's Love in a Headscarf", Journal of Muslim Minority Affairs, 35(I), pp. 89-I05.

Lefort, R. (I97I). Teachers of Gurdjieff. TheOctagon Press.

Lessing, D. (I980). The Marriages Between Zones Three, Four and Five. Jonathan Cape.

Lewis, F.D. (2000). Rumi: Past and Present, East and West: The Life, Teachings and Poetry of Jalla al-Din Rumi. Oneworld.

Mahmood, S. (2005). Politics of Piety: The Islamic Revival and the Feminist Subject. Princeton UP.

Moore, J. (I986). "Neo-Sufism: The Case of Idries Shah,” Religion Today, 3(3), pp. 4-8. 
Nash, G. (2007). The Anglo-Arab Encounter in Fiction and Autobiography by Arab Writers in English. Peter Lang.

- (2012). Writing Muslim Identity. Continuum.

Phillips, C. (2012). “Leila Aboulela's The Translator: Reading Islam in the West,"Wasafiri. 27(I), pp. 66-72.

Rashid, C.E. (20I2). "Islamic Individualism and the Logic of the Narrative," Interventions, I4(4), pp. 613-624.

Santesso, E. (2013). Disorientation: Muslim Identity in Contemporary Anglophone Literature. Macmillan.

Sarnov, D. (2014). "Narratives of Arab Anglophone Women and the Articulation of a Major Discourse in a Minor Literature," Journal of International Studies, I6(I), pp. 65-8I.

Sedgwick, M. (2003). Sufism: The Essentials. The American University in Cairo Press.

Shah, I. (I982a). A Perfumed Scorpion, The Octagon Press.

- (1982b). Seeker After Truth: A Handbook. The Octagon Press. 